\title{
Influence of weather condition on selected tomato varieties in response to season of sowing in akure, a rainforest zone of Nigeria
}

\begin{abstract}
Most of the third world nations are more vulnerable to climate change because of their agricultural operations depends solely on the outcome of the climatic conditions, low levels of agro-technology skill, low levels of human and physical capital, inequitable land distribution and poor infrastructure. Hence, solving the problem of climate change on food production and security is one of the biggest challenges faced by most developing nations. This study was conducted to assess the tomato crop-climate factor relationships, the results of which will be useful components in the search for adaptation strategies relevant to smallholder farmers in the face of a changing climate and extreme weather and the consequences on food production and security. Four varieties of tomato were evaluated during the rainy and dry cropping seasons on a field in Akure, Nigeria. The sowing seasons were characterized by varying weather events for tomato production. The sowing dates were implemented to determine the best sowing seasons with respect to growth and fruit yield. The results show that tested varieties perform differently in the sowing seasons for the measured growth and yield characters, Ibadan local and Beske were the best recording $35.9 \% \& 39 \%$ of the total yield compared to Roma VF and UC varieties. first planting (March-June) showed more positive responses climatic variables compared to Second planting season (August - December) especially in term of yield quantity and quality. Early season planting recorded $16 \%$ higher amounting to about $115 \mathrm{~kg} / \mathrm{ha}$ in fruit weight than lateseason planting. Therefore based on desirable traits, the best varieties (Ibadan local and Beske) are recommended to solve the problem of scarcity to ensure food security. Information so generated from the soil-crop-climate relationships will contribute to planning responses and strategies for adaptation to future climate change.
\end{abstract}

Keywords: tomato, climate variability, management, sowing dates humid zone
Volume 2 Issue 6 - 2018

\author{
Oladitan TO,' Oluwasemire $\mathrm{KO}^{2}$ \\ 'Department of Crop, Soil and Pest Technology, Rufus Giwa \\ Polythecnic, Nigeria \\ ${ }^{2}$ Department of Agronomy, University of Ibadan, Nigeria
} Correspondence: Oladitan TO, Department of Crop, Soil and
Pest Technology, Rufus Giwa Polythecnic, Nigeria,

Email titipraise@yahoo.com

Received: August 08, 2018 | Published: December 28, 2018

\section{Introduction}

A momentous change in climate on a universal scale will impact agriculture and accordingly affect the world's food supply. Climate change intrinsically is not necessarily harmful but the problems arise from events that are difficult to predict. ${ }^{1}$ The records of inconsistent rainfall patterns and unpredictable high temperature spells consequently reduce crop productivity in the tropics. Latitudinal and altitudinal shifts in ecological and agro-economic zones, land degradation, extreme geophysical events, reduced water availability, the rise in sea level and salinization are suggested, ${ }^{2}$ unless prompt decision are undertaken to mitigate the effects of climate change, food security in developing countries will be under threat. In the humid tropics, the rainy (wet) and late (dry) sowing seasons are associated with changes in climatic attributes which to a great extent influence the productivity of agricultural food (vegetable crops). ${ }^{3}$ Crop growth and yield response to the available environmental resources of the growing seasons. The sowing seasons and the productivity input determine the optimum productivity of species of any crop.

Vegetable crops production during the wet/rainy season is becoming increasingly attractive for cash generation for farmers of humid agro climatic zone, but, the productivity of the crop is very low due to several production problems like high mortality of seedlings at nursery stage, high incidence disease such as leaf curl virus, early and late blight diseases among others, low fruit set, poor fruit quality and non-availability of suitable adaptable varieties to seasonal variability ( unpredictable rainy or hot and dry seasons), thus, limiting their cultivation on a commercial scale, resulting to high price value and a lot of dependence on other region to meet the demand for consumption. ${ }^{4}$ Vegetables are the best means of overcoming micronutrient deficiencies and provide peasant farmers with sustanance income and more jobs per hectare than staple crops. ${ }^{5}$ Broadly, vegetable crops are sensitive to environmental condition, high temperatures and excessive soil moisture (rainfall),which are the major causes of low yields in the tropics and this can be further exaggerated by other climatic factors such as radiation and cloud cover. ${ }^{6}$ Tomato, cabbage, onion, hot pepper and eggplant are among few important vegetables consumed and or processed for utilization in Asia and Sub-Saharan Africa region. ${ }^{7}$ Tomato (Lycopersicon esculentum Mill.), an important horticultural crop grown worldwide is a fruit vegetable belongs to the Solanaceae. It is one of the most popular and nutritious vegetable crops all over the world including Nigeria, a very cheap source of vitamins, important in the metabolic activities of man. ${ }^{8,9}$ Tomato production in Nigeria has been reported to be $1,701,000$ tons over an area of 265,000 ha. ${ }^{10}$ yet its yield production in the forest humid zone of Nigeria is relatively low compared with average existing data of $14 \mathrm{t} / \mathrm{ha}-1$ from the world record. ${ }^{8,10,11}$ 
The limitation in yield production had been majorly soil and climatic factors (temperature, humidity and rainfall). In the months of March through June, little production takes place due to high intensity of rainfall events that exert their toll on tomato by reducing flowering, fruit-set and yield (AVRDC 2002). The associated high humidity in the ecological zone is accompanied by fungal diseases that attack the crop. ${ }^{12}$ Effect of rainfall may differ depending on the rainfall characteristics (drop size, intensity and duration) and the crop growth stage exposed to rain. In order to improve the productivity of tomato in the various cropping opportunities, it is necessary to understand production risks with decision options in circumstances of soil and climatic factors of a growing season. ${ }^{3}$ The contrasting seasonal weather conditions offered a valuable framework for studies of the challenges and potentials of crop-environment-management interactions to contribute to improve understanding of tomato responses to growing season weather factors. The objective of this study therefore, is to understudy the importance of environmental factors, crop characteristics and fruit yield of tomato for better performance during the rainy and late season periods in Akure, a forest rainforest zone of Nigeria.

\section{Methodology}

Data Collection: This study was carried out at the Research Farm of the Federal University of Technology, Akure, (lat $7.17^{\circ} \mathrm{N}$, long $5.8^{\circ} \mathrm{E}$ ), a tropical rainforest zone of southern Nigeria The climate of the area was characterized by heavy rainfall during the months from April to July and August to November. The sandy loam soil at the site of study is an alfisol classified as clayey skeletal oxic- paleustalf (USDA Soil Survey Staff, 1999). The nutrient status of surface soil for $0-15 \mathrm{~cm}$ at the experimental site before planting are: $\mathrm{pH} 6.8 ; \mathrm{N}$ $(0.19 \mathrm{mg} / \mathrm{kg}) ; \mathrm{P}(7.69 \mathrm{mg} / \mathrm{kg}) ; \mathrm{K}, \mathrm{Ca}$ and $\mathrm{Mg}(1.75,0.84,4.39 \mathrm{cmol} /$ $\mathrm{kg}$ soil respectively); organic matter $(2.42 \mathrm{~g} / \mathrm{kg})$, bulk density $(1.28$ $\left.\mathrm{mg} / \mathrm{m}^{3}\right)$. The field site was manually cleared. Seeds of four tomato varieties: Ibadan local (Ib. local), UC, Roma VF and Beske were nursed on 5th of March, 2012 for early/raining season planting and transplanted to the field on $2^{\text {nd }}$ of April, 2012.The late season planting was on $4^{\text {th }}$ of September and transplanted to the field on $1^{\text {st }}$ of October. The experiment was repeated in the cropping seasons of year 2013 The experimental design was a Randomized Complete Block Design (RCBD) with three replications. The unit plot size was $2 \mathrm{~m} \times 2 \mathrm{~m}$. The tomato variety seeds were nursed in a well pulverized rich loamy soil and was transplanted into the field after 5 weeks at a planting distance of $90 \mathrm{~cm}$ by $30 \mathrm{~cm}$. Two weeks interval records of plant height $(\mathrm{cm})$, number of leaves per plant, leaf area per plant $\left(\mathrm{cm}^{2}\right)$, dry weight of leaves and fruits per plant $(\mathrm{g})$, number of flower clusters per plant, number of fruits per plant, weight of individual fruit $(\mathrm{g})$, weight of fruits per plant $(\mathrm{kg})$, weight of fruits per plot $(\mathrm{kg})$ and fruit yield $(\mathrm{t} / \mathrm{ha})$ were taken up to maturity and tomato yield was assessed at the final harvest. Weather data includes rainfall (RR), maximum temperature (T_max), minimum temperature (T_min) and relative humidity $(\mathrm{R} / \mathrm{H})$ was taken simultaneously on weekly basis in two planting seasons. Data were analyzed to establish the relationship between various growth stages and weather elements considered using bi-variate correlation method and ANOVA.

\section{Results and discussion}

The mean monthly weather observations recorded from the meteorological unit, (Table 1) shows that higher rainfall was recorded in the 2013 wet $(489.5 \mathrm{~mm})$ season than in the 2012 wet $(466.6 \mathrm{~mm})$ season. Dry season rainfall was very minimal. Relative humidity for the wet season was higher $(90.4 \%$ and $90.5 \%$ in 2012 and 2013 respectively), however, it was relatively high throughout the year. Mean temperature for the two years ranges from $21-30^{\circ} \mathrm{C}$. Mean daily sunshine was similar for both years in the dry (approximately $6.22 \mathrm{hrs}$ ). The result of analysis of variance on crop parameter revealed yield differences among the tested varieties which indicate the need for selection of suitable variety for the sowing seasons. The mean performance of the varieties in respect of plant height, number of branches, days to flowering, days to first harvest of fruits after transplanting, plant stand at harvest and incidence of disease as shown in Table $2 \&$ Table 3 . All tested varieties recorded similar growth pattern. Among the varieties, the highest plant height (123.4 $\mathrm{cm})$ was recorded in Ibadan local, followed by Beske $(104.7 \mathrm{~cm})$, and Roma. This trend was consistent for growth and yield parameters. The variety Ibadan local took the earliest day to $50 \%$ time to flower $(53.3$ days) during the late season sowing, followed by Beske (45.3 days) and UC (56.90 days). Late season crops flowered earlier than the rainy season planting. Similarly, the cultivar Ibadan local took 73.14 days to attain first fruit harvest and thus was the earliest one, while Roma fruit harvest commenced later (83.18 days to the first harvest). During dry season, the precipitation and relative humidity is low while they were in the wet season, this high precipitation and relative humidity favours the production of huge biomass, and the fruit tend to be lowered for varieties that have no ecological adaptation. Agele et al. ${ }^{4}$ reported the effects of variations in soil moisture and thermal regimes during the pre and reproductive stages in the respective rainy and late seasons of sowing on the growth and yield of tomato. The days to first harvest is envisaged as an index of earliness and plant stand at harvest in a variety is one of the important parameters for rainy and off-season production of tomato. These parameters determine the resistance and tolerance of a variety to a particular environment and incidence of pests and diseases. In Table 4 presented the relationships of growth and yield parameters with some weather variables. The results showed that there were strong relationships which were positive and negative in some cases) between the tomato varieties phenological characteristics with amount of rainfall, mean temperature and at 5\% s.g.l. However, $\mathrm{R}^{2}$ values varies from high to low (strong and weak relationships).

Table I Monthly data record for the year 2012 and 2013

\begin{tabular}{lllllllllllll}
\hline 2012 & J & F & M & A & M & J & J & A & S & O & N & D \\
\hline DWN & 34.0 & 35.8 & 37.5 & 37.5 & 36.4 & 35.5 & 35.7 & 36.7 & 37.0 & 36.1 & 34.4 & 33.2 \\
LWV & 35.1 & 36.3 & 37.5 & 37.5 & 37.5 & 37.3 & 37.0 & 37.3 & 37.3 & 37.2 & 36.7 & 35.0 \\
Tmean & 25.9 & 26.5 & 26.7 & 26.6 & 26.0 & 25.2 & 24.3 & 24.6 & 24.8 & 25.1 & 25.4 & 25.2 \\
Tmin & 21.9 & 22.9 & 23.8 & 23.5 & 23.3 & 22.8 & 22.0 & 21.8 & 22.4 & 22.6 & 22.8 & 21.6 \\
Tmax & 30.4 & 31.0 & 30.7 & 30.6 & 29.6 & 28.5 & 27.5 & 28.4 & 28.0 & 28.6 & 28.6 & 29.2 \\
RH & 89.1 & 83.4 & 84.7 & 84.4 & 87.0 & 89.4 & 90.4 & 88.2 & 90.5 & 89.4 & 89.9 & 83.7 \\
\hline
\end{tabular}


Table Continued....

\begin{tabular}{|c|c|c|c|c|c|c|c|c|c|c|c|c|}
\hline 2012 & J & $\mathbf{F}$ & $\mathbf{M}$ & A & $\mathbf{M}$ & J & J & A & $\mathbf{S}$ & O & $\mathbf{N}$ & D \\
\hline Rain & 51.6 & 99.1 & 120.0 & 439.2 & 281.4 & 466.6 & 119.6 & 83.6 & 343.6 & 247.5 & 411.5 & 101.6 \\
\hline wind speed & 1.9 & 2.2 & 2.4 & 2.1 & 2.0 & 2.2 & 2.5 & 2.6 & 2.2 & 1.9 & 1.8 & 1.9 \\
\hline \multicolumn{13}{|l|}{2013} \\
\hline DWN & 34.0 & 36.0 & 37.5 & 37.5 & 36.2 & 35.5 & 35.7 & 36.8 & 37.1 & 36.1 & 34.4 & 33.2 \\
\hline Tmean & 25.9 & 26.5 & 26.5 & 26.2 & 26.2 & 25.6 & 24.8 & 24.5 & 24.5 & 25.1 & 25.7 & 25.9 \\
\hline Tmin & 22.1 & 22.8 & 23.6 & 23.4 & 23.3 & 23.3 & 22.2 & 21.9 & 22.2 & 22.6 & 22.8 & 21.9 \\
\hline Tmax & 30.3 & 31.1 & 30.3 & 29.9 & 29.8 & 28.8 & 28.4 & 28.0 & 27.8 & 28.3 & 29.2 & 30.3 \\
\hline $\mathrm{RH}$ & 79.1 & 81.2 & 85.5 & 86.2 & 86.5 & 89.8 & 89.4 & 89.3 & 90.5 & 90.0 & 88.1 & 77.8 \\
\hline Wind speed & 1.8 & 1.9 & 2.3 & 2.1 & 1.8 & 2.2 & 2.6 & 2.5 & 2.2 & 1.9 & 1.7 & 1.6 \\
\hline
\end{tabular}

Table 2 Growth and yield characters of Tomato varieties as affected by cultivars and season of sowing

\begin{tabular}{|c|c|c|c|c|c|c|c|}
\hline $\begin{array}{l}\text { Tomato } \\
\text { varieties }\end{array}$ & $\begin{array}{l}\text { Root dry } \\
\text { wt.(g) }\end{array}$ & $\begin{array}{l}\text { Shoot dry } \\
\text { wt.(g) }\end{array}$ & $\begin{array}{l}50 \% \text { flowering } \\
\text { date }\end{array}$ & $\begin{array}{l}\text { No of fruit/ } \\
\text { plant }\end{array}$ & $\begin{array}{l}\text { Harvest } \\
\text { Duration(days) }\end{array}$ & $\begin{array}{l}\text { fruit yield(t/ } \\
\text { ha) }\end{array}$ & HI \\
\hline \multicolumn{8}{|l|}{ Rainy season } \\
\hline Ibadan local & 6.4 & 22.2 & 76 & 31 & 52 & 3.65 & 0.45 \\
\hline Beske & 6.3 & 20 & 74 & 33.5 & 44.5 & 3.51 & 0.59 \\
\hline Roma & 3.8 & II. 4 & 65 & 18 & 29 & 0.96 & 0.28 \\
\hline Uc & 4.6 & 15.6 & 63 & 16 & 29.6 & 1.25 & 0.48 \\
\hline Lsd (0.05) & 0.9 & I.I & 4 & 5.2 & 7 & 1.12 & 0.05 \\
\hline \multicolumn{8}{|l|}{ late season } \\
\hline Ibadan local & 5.75 & 26.7 & 73 & 26 & 47 & 2.12 & 0.27 \\
\hline Beske & 6.7 & 15.2 & 70 & 26 & 24.5 & 2.95 & 0.32 \\
\hline Roma & 3.2 & 8.4 & 63 & 16 & 23 & 1.86 & 0.28 \\
\hline Uc & 3.6 & 7.6 & 65 & 10 & 24.6 & 1.45 & 0.19 \\
\hline Lsd (0.05) & 1.2 & 0.7 & 6 & 6.4 & 4 & 0.73 & 0.06 \\
\hline
\end{tabular}

*significant at $\mathrm{P}<0.05$

Table 3 Growth and yield early rainfed and late rainfed season of tomato

\begin{tabular}{|c|c|c|c|c|c|c|c|}
\hline Seasons of sowing & $\begin{array}{l}\text { Root wt } \\
\text { (g) }\end{array}$ & $\begin{array}{l}\text { Shoot } \\
\text { wt (g) }\end{array}$ & $\begin{array}{l}\text { No. of } \\
\text { branches }\end{array}$ & $\begin{array}{l}\text { Plant height } \\
(\mathrm{cm})\end{array}$ & $\begin{array}{l}\text { Date of } 50 \% \\
\text { flowering (days) }\end{array}$ & $\begin{array}{l}\text { Fruit } \\
\text { weight(g) }\end{array}$ & $\begin{array}{l}\text { Fruit yield } \\
\text { (kg/ha) }\end{array}$ \\
\hline Rainy(Rainfed) (March- June) & 14.7 & 33.1 & 22 & 122 & 56 & 15720 & 4.37 \\
\hline Late (Rainfed) (August-December) & 13.4 & 31.2 & 19 & 109 & 54 & 12847 & 3.12 \\
\hline
\end{tabular}

Table 4 Varietal effects (across the seasons) on the performance of tomato

\begin{tabular}{|c|c|c|c|c|c|c|c|c|}
\hline Varieties & $\begin{array}{l}\text { Root wt } \\
\text { (g) }\end{array}$ & $\begin{array}{l}\text { Shoot wt } \\
\text { (g) }\end{array}$ & $\begin{array}{l}\text { No. of } \\
\text { branches }\end{array}$ & $\begin{array}{l}\text { Plant height } \\
(\mathrm{cm})\end{array}$ & $\begin{array}{l}\text { Date of } 50 \% \\
\text { flowering (days) }\end{array}$ & $\begin{array}{l}\text { Fruit } \\
\text { weight(g) }\end{array}$ & $\begin{array}{l}\text { Fruit yield } \\
\text { (kg/ha) }\end{array}$ & $\begin{array}{l}\text { Harvest } \\
\text { index }\end{array}$ \\
\hline Beske & 11.24 & 1210.3 & 17.3 & 104.7 & 54.3 & 346.9 & 19354.7 & 0.31 \\
\hline Ibadan local & $1 \mathrm{I} .43$ & 1950 & 21 & 123.4 & 53.3 & 369.5 & 20447.3 & 0.22 \\
\hline Roma vf & 7.82 & 415.3 & 11.3 & 80 & 55.7 & 134.8 & 9320.2 & 0.33 \\
\hline UC & 9.9 & 330.5 & 9.7 & 76 & 56 & 120.2 & 6348.2 & 0.33 \\
\hline
\end{tabular}


There were good correlation between the weather parameters and tomato varieties with respect to plant biomass, earliness to flower, number of fruits/plant, fruit weight and fruit yield observed, shoot biomass, and temperature for both sowing season was high (97\%), shoot biomass with rainfall and temperature were $98 \%$ and $97 \%$ respectively TPLA and HI were (71\%) but very weak for the fruit weight $(35 \%)$ as shown in Table 4 .This may this could be attributed to hydrothermal sensitivity of physiological processes (production of leaves, increase in plant height and attainment of anthesis).the report is in line with the findings of Pressman et al., (2002) and Agele et al. ${ }^{13}$ It can also be attributed to the more favourable environmental conditions experienced during the wet season as compared with that of the dry season. Changes in environmental conditions have been reported to influence growth and development of tomato Table $5 .{ }^{3}$

Table 5 Association of weather factors with crop growth and yield characters of tomato

\begin{tabular}{|c|c|c|}
\hline Plant parameters/Weather factors & Regression equation & $\begin{array}{l}\text { Coefficient of } \\
\text { determination }\left(R^{2}\right)\end{array}$ \\
\hline \multirow[t]{2}{*}{ Shoot biomass and rainfall } & $\mathrm{rsc}^{*} y=2.92 x+180.3$ & 0.98 \\
\hline & $I s c^{*} y=1.36-8.24$ & 0.96 \\
\hline \multirow[t]{2}{*}{ Shoot biomass and mean $\mathrm{T}^{\circ} \mathrm{C}$} & $r s c y=-53.6 \times 2+2 \mid 7-214$ & 0.97 \\
\hline & Isc $y=-53.2 x-148$ & 0.97 \\
\hline \multirow[t]{2}{*}{ TPLA and rainfall } & $\mathrm{rsc} y=0.14 x+0.04$ & 0.8 \\
\hline & Isc $y=0.57 x+0.1$ & 0.9 \\
\hline \multirow[t]{2}{*}{ TPLA and mean $\mathrm{T}^{\circ} \mathrm{C}$} & $r s c y=0.08 x+2.1$ & 0.35 \\
\hline & Isc $y=0.1 x+2.5$ & 0.35 \\
\hline \multirow[t]{2}{*}{ Fruit yield and rainy days } & $r s c y=0.08 x+2.1$ & 0.35 \\
\hline & Isc $y=0.1 x+2.5$ & 0.35 \\
\hline \multirow[t]{2}{*}{ Fruit yield and mean $\mathrm{T}^{\circ} \mathrm{C}$} & $r s c y=0.08 x+2.1$ & 0.35 \\
\hline & Isc $y=0.1 x+2.5$ & 0.35 \\
\hline \multirow[t]{2}{*}{$\mathrm{HI}$ and rainfall } & $\operatorname{rsc} y=0.16 x+0.04$ & 0.47 \\
\hline & Isc $y=0.21 x+0.07$ & 0.71 \\
\hline \multirow[t]{2}{*}{$\mathrm{HI}$ and mean $\mathrm{T}^{\circ} \mathrm{C}$} & $r s c y=0.08 x+2.1$ & 0.35 \\
\hline & Isc $y=0.1 x+2.5$ & 0.35 \\
\hline
\end{tabular}

TPLA, Total plant leaf area; rsc, Rainy season crop; Isc, Late season crop

\section{Conclusion}

The reproductive phase of tomato varieties shows a positive association with the amount of rainfall during this phase this is in line as reported by Jones et al.,2012 in Muhammad et al., ${ }^{14}$ The correlation between the flowering, fruiting were positive and statically significant at $5 \%$ level. However, Roma, VF, variety has a negative correlation. These relationships indicated that weather factors are important to growth and processes of yield determination among the tomato varieties evaluated. The weather indices have a direct impact on the production of tomato. ${ }^{15-21}$

\section{Acknowledgment}

None.

\section{Conflicts of interest}

The authors declare that there is no conflict of interest.

\section{References}

1. FAOSTAT. Food and Agriculture Organization of the United Nations. 2014

2. Food and Agriculture Organization (FAO). Year book Production 2014. Rome: FAO. Tomato production statistic. 2014.
3. Agele SO, Iremiren GO, Ojeniyi SO. Evapotranspiration, Water use efficiency and yield of rainfed and irrigated tomato. International Journal of Agricultural and Biological science. 2011;13:469-476.

4. Agele SO, Olufayo A, Iremiren GO. Effects of season of sowing on water use and yield of tomato in the humid south of Nigeria. Afr Crop Sci J. 2002;10(3):231-237.

5. AVRDC. Effect of staking and mulching on Tomato yield. Progress Report. AVRDC Shanhua: Taiwan. 1995;407-408.

6. Hasnson P. Cultivation of Tomato and seed Development Training office, Asian vegetable Research and Development center. Shanbua, Taian Taiwan. 2010

7. Ebimieowei E, Nwauzoma AB, Bawo DDS. Postharvest Spoilage of Tomato (Lycopersicon esculentum Mill.) and Control Strategies in Nigeria. Journal of Biology, Agriculture and Healthcare. 2013;3(10):2123.

8. Bodunde JG, Olarewaju JD, Erinle ID. Tomato response to planting arrangement types during dry -hot seasons in the northern. Guinea Savannah of Nigeria. 1991;48(3-4):337-340.

9. Mehdizadeh M, Darbandi EI, Naseri-Rad H, et al. Growth and yield of tomato(Lycopersicon esculentum Mill.) as influenced by different organic fertilizers. International Journal of Agronomy \& Plant Production. 2013;4(4):734-738.

10. FAOSTAT. Food and Agriculture Organization Statistics (FAOSTAT). 2013. 
11. Food and Agriculture Organization of United Nation. Production Year Book. 2008;326.

12. Aniso J, Hamadina EI, Hamadina MK. Germination and Vegetative Growth of Selected Hybrid Tomato (Lycopersicum esculentum Mill.) Cultivars under Hot and Wet Environmental Conditions in Rivers State. Nigeria. Journal of Plant Sciences. 2015;3(2):99-105.

13. Agele SO. Weather and seasonal effects on growth, seed yield and soluble carbohydrate concentrations in selected maize cultivars in the humid areas of Nigeria. African Journal of Agricultural Research. 2006;1(4):101-110.

14. Muhammad Irfan Ahmad, Amjed Ali, Muhammad Asghar Ali, et al. Use of Crop growth in Agriculture: A review. Sci Int (Lahore). 2014;26(1):331-334.

15. Anon. A guide to production of some vegetables. NIHORT'S extension guide No. 8. 1989.
16. Ewulo BS, Ojeniyi SO, Akanni DA. Effect of poultry manure on selected Soil physical and chemical properties, growth, yield and nutrient status of tomato. African Journal of Agricultural Research. 2008;3(9):612-616.

17. International Institute of Tropical Agriculture (IITA). Selected method for soil and plant analysis manual series No 6.J. 1982;43:434-438.

18. Kabura BH, Odo PE, Abubakar A. Perfomance of some tomato varieties under Heat Period in Northern Nigeria. J Agronomy. 2008;8(1):45-48.

19. Nahar K, Gretzmacher R. Effect of water stress on nutrient uptake, yield and quality of tomato (Lycopersicon esculentum Mill.) under subtropical conditions. 2002;53(1):2002.

20. South Pacific Foods. Green leaves in South Pacific Food Leaflet. South pacific Commission community Health Service 6 Leaflet. 1995.

21. Taylor JH. Text of lectures delivered at the national workshop on fruit and vegetable seedlings production held at NIHORT. 1987;9-13. 